\title{
La borradura del rostro: prácticas artísticas y el problema de la visibilidad de las víctimas
}

Juan Carlos Arias Herrera ${ }^{1}$

Recibido: 25/06/2018

Aprobado por pares: 25/07/2018
Enviado a pares: 09/07/2018

Aceptado: 21/09/2018

DOI: $10.5294 /$ pacla.2019.22.2.4

Para citar este artículo / to reference this article / para citar este artigo

Arias Herrera, J. C. (2019). La borradura del rostro: prácticas artísticas y el problema de la visibilidad de las víctimas. Palabra Clave, 22(2), e2224. DOI: 10.5294/pacla.2019.22.2.4

\section{Resumen}

El presente texto inadaga una de las estrategias más comúnes a la hora de hacer visibles a las víctimas del conflicto en Colombia: la exposición de sus rostros. A través del concepto de sobreexposición propuesto por Georges Didi-Huberman, se cuestiona la efectividad de dicha estreategia frente a las distintas prácticas de borradura que han intentado invisibilizar a las víctimas. Por medio de una reinterpretación de la noción de borradura, se busca mostrar la potencia de pensar el rostro como multiplicidad más que como matriz de identidad a la hora de hacer visibles la violencia que ha afectado a miles de personas durante décadas.

\section{Palabras clave (fuente: Tesauro de la Unesco)}

Víctima; víctima de guerra; visibilidad; percepción; artes; exposición cultural; rostro; borradura; memoria colectiva.

1 orcid.org/0000-0002-6197-906X. Pontificia Universidad Javeriana, Colombia. arias.juan@javeriana.edu.co 


\section{Face Blurring: Artistic Practices and the Issue of the Visibility of Victims}

\section{Abstract}

This article explores one of the most common strategies to make victims of the conflict in Colombia visible: exposing their faces. Based on Georges Didi-Huberman's concept of overexposure, the effectiveness of this strategy is questioned with respect to various blurring practices that have tried to make victims invisible. In reinterpreting the notion of blurring, it seeks to show the power of thinking of the face as a multiplicity rather than as an identity matrix when it comes to spotlighting the violence that has affected thousands of people for decades.

\section{Keywords (source: Unesco Thesaurus)}

Victim; war victims; visualization; perception; arts; cultural exhibitions; face; erasure; collective memory. 


\section{Ocultamento do rosto: práticas artísticas e 0 problema da visibilidade das vítimas}

\section{Resumo}

O presente texto questiona uma das estratégias mais comuns na hora de tornar as vítimas do conflito na Colômbia visíveis: a exposição de seus rostos. Através do conceito de superexposição proposto por Georges Didi-Huberman, questiona-se a eficácia dessa estratégia diante das diferentes práticas de ocultamento que tentaram invisibilizar às vítimas. Através de uma reinterpretação da noção de ocultamento, procura-se mostrar o poder de pensar o rosto como uma multiplicidade e não como uma matriz de identidade quando se trata de tornar visível a violência que afetou milhares de pessoas durante décadas.

\section{Palavras-chave (Fonte: tesauro da Unesco)}

Vítima; vítima da guerra; visibilidade; percepção; artes; exposição cultural; rosto; ocultamento; memória coletiva. 
Toda forma es un rostro que nos mira.

Serge Daney

\section{Introducción}

El 10 de junio de 2011, el Congreso de la República de Colombia aprobó la Ley de Víctimas y Restitución de Tierras a través de la cual se creaba una serie de medidas dirigidas a la atención, asistencia y reparación integral de las víctimas del conflicto armado interno que ha afectado al país por más de siete décadas. Además de proveer un marco para la definición institucional de quién puede considerarse como víctima, y de una exhaustiva lista de las situaciones de violencia que victimizan a una persona o un colectivo (homicidio, desaparición forzada, desplazamiento, violaciones sexuales, secuestro, despojo de tierras, entre muchas otras), esta ley se concentró en sistematizar una serie de medidas judiciales, administrativas, sociales y económicas que hicieran posible "el goce de sus derechos a la verdad, la justicia y la reparación con garantía de no repetición, de modo que se reconozca su condición de víctimas y se dignifique a través de la materialización de sus derechos constitucionales" (Ley 1448/2011, de 10 de junio, por la cual se dictan medidas de atención, asistencia y reparación integral a las víctimas del conflicto armado interno y se dictan otras disposiciones). Uno de los aspectos centrales contemplados en esta ley, dirigidos al reconocimiento y la reparación integral, es la visibilidad de las víctimas.

La noción de visibilidad abarca desde el mismo reconocimiento institucional de un individuo como "víctima" (categoría que se adquiere legalmente al cumplir ciertos requisitos de registro), hasta el reconocimiento público y social, proporcionado, en la mayoría de los casos, por espacios mediáticos y de producción cultural. Cientos de iniciativas que buscan dar visibilidad a los relatos y a las experiencias de las víctimas han surgido desde entonces a partir de diversos ámbitos de la vida pública nacional. La instauración, desde 2011, del Día Nacional de la Memoria y Solidaridad con las Víctimas del Conflicto Armado, cada 9 de abril, es un ejemplo paradigmático en este sentido. El alto consejero para el posconflicto, Rafael Pardo Rueda, afirmó en diciembre de 2015 que uno de los grandes logros del Gobierno colombiano había sido, precisamente, darles visibilidad a las víctimas del conflicto, las cuales habían permanecido invisibles en el imaginario nacional: "Hace 
tres o cuatro años nadie pensaba en víctimas, hasta que apareció la Ley de Víctimas $[. .$.$] Las víctimas han aparecido en el escenario con voz, con de-$ rechos, con reclamos, y muchos son legítimos, otros son producto de mala información [...] Este gobierno le dio visibilidad a la víctimas" (El País, 2015). Nuestro presente está marcado por esta aparición, por la necesidad de hacerla perdurar. Usando las palabras de Didi-Huberman (2013), parece que "los pueblos son hoy más visibles de lo que jamás lo han sido" (p. 17).

El imperativo de dar visibilidad a un pueblo que parecía destinado a desaparecer, en este caso las víctimas del conflicto, está directamente relacionado con la posibilidad de producción de memoria colectiva. Como afirma Benjamin (2012), "a la memoria de los sin nombre está dedicada la construcción histórica” (p. 405). El imperativo consiste en exponer a los sin nombre con el fin de extraer de ellos una "parcela de humanidad" en tiempos en los que reina la crueldad y lo inhumano (Didi-Huberman, 2014, p. 25). El exdirector del Museo de Memoria Histórica de Colombia, Juan Carlos Posada, sintetizaba esta idea en una entrevista de 2013 en la que explicaba la importancia de escuchar los testimonios de las víctimas del conflicto en Colombia como medio fundamental de reconocimiento y construcción de memoria. Sus palabras señalan el valor del ejercicio del dar la voz, el cual parece haberse convertido en un propósito nacional hace ya más de una década:

Creo que lo fundamental es precisamente que, en ese sentido de la reparación integral, la voz de las víctimas es esa otra mirada que nunca ha sido escuchada, que nunca ha sido visibilizada, que siempre ha estado un poco en la oscuridad. Y que en este conflicto de más de seis décadas, hemos escuchado a los actores institucionales, hemos escuchado incluso a los actores armados, a los actores al margen de la ley, y las víctimas no han tenido realmente un espacio donde cuenten qué les pasó, cómo les pasó, dónde les pasó, qué hicieron para soportar ese horror. (Urna de Cristal, 2013)

La pregunta que debe formularse ante este tipo de afirmaciones es qué tipo de visibilidad han adquirido los sin nombre, cuáles son las estrategias que se han usado para producir tal visibilidad y qué consecuencias han tenido dichas estrategias en el objeto mismo que se quiere hacer visible. 
Didi-Huberman (2014) condensa estos interrogantes en el concepto de exposición, el cual adquiere en su análisis un doble sentido, aparentemente contradictorio: los pueblos están expuestos, en el sentido de haber conseguido visibilidad, de estar representados. Pero también están expuestos al peligro de la desaparición, de la invisibilidad. La noción de exposición condensa la posibilidad de ser visibles y la inminencia del desvanecimiento. ¿Se ha conjurado el peligro de la desaparición y el olvido a través de las distintas dinámicas de visibilización y exposición de las víctimas en Colombia? ¿La exposición que da visibilidad ha desvanecido la exposición por desaparecer? ¿La solución al asunto de la visibilidad radica realmente en la disolución de ese peligro a través de la representación? En este trabajo, propongo que las prácticas que dan visibilidad no siempre son opuestas al peligro de la desaparición, sino que en ocasiones ciertas formas de visibilidad son precisamente las que exponen a un pueblo a desaparecer. Entendidas de este modo, visibilidad y desaparición no son categorías opuestas y excluyentes, sino que construyen una relación más compleja que incluso puede llevarnos a pensar en la posibilidad de comprender ciertos tipos de borradura como prácticas de visibilización.

\section{Entre la voz y el rostro}

Sarlo (2005) ha señalado lúcidamente cómo, desde hace algunas décadas, dar la voz se ha establecido como el paradigma fundamental en la construcción de la memoria histórica. El problema de exponer a los sin nombre ha encontrado solución a través de lo que Sarlo llama el "giro subjetivo": "La histora oral y el testimonio han devuelto la confianza en esa primera persona que narra su vida (privada, pública, afectiva, política), para conservar el recuerdo o para reparar una identidad lastimada" (p. 22). Este es el supuesto fundamental que se revela en los ejercicios de visibilidad de las víctimas en distintos contextos de conflicto: dar la voz se establece como el medio privilegiado para acceder a la verdad y, en esa medida, para devolverle la dignidad a quienes han padecido las consecuencias de la violencia. Retomando los términos planteados por Didi-Huberman (2014), dar la voz se ha convertido en el imperativo paradigmático para exponer a los pueblos que estaban destinados a desaparecer. 
Uno de los puntos más interesantes en el análisis de Didi-Huberman (2014), sin embargo, está en mostrar que en muchas ocasiones las prácticas y dinámicas que apuntan a hacer desaparecer a un pueblo, las cuales son muy diversas y van desde masacres, torturas y violencia explícita, hasta ejercicios discursivos institucionales de reducción del otro, no están tan distantes de aquellas prácticas que intentan exponerlos al darles la voz. Este punto queda claro al analizar las dos formas centrales de invisibilización de un pueblo propuestas por el autor: la subexposición y la sobreexposición.

El primer término hace referencia a procesos que históricamente asociamos a las prácticas de invisibilización: la censura en sus distintas formas, la desaparición, la violencia directa sobre los cuerpos. Sin embargo, señala Didi-Huberman (2014), la invisibilización no funciona solo a través de procedimientos negativos de sustracción y borrado. Nuestra época ha creado una forma de invisibilizar al otro quizá más perversa: el exceso espectacular de representaciones. Didi-Huberman (2014) señala que "los pueblos están expuestos a desaparecer porque están subexpuestos a la sombra de sus puestas bajo la censura o, a lo mejor, pero con un resultado equivalente, sobreexpuestos a la luz de sus puestas en espectáculo [las cursivas son mías]" (p. 14). Este exceso, cabe aclarar, no es un asunto de cantidad. No se pueden tener demasiadas imágenes de las víctimas, por ejemplo. El problema es de sobrecodificación: ciertas representaciones son repetidas y amplificadas dentro de ciertos formatos que deben resultarnos familiares para que encontremos en ellas algo de verdad. Es decir, para ponerlo respecto del paradigma de dar la voz, nos hemos acostumbrado a que el otro hable de un modo particular. No a que diga lo mismo cada vez que habla, sino a que su palabra adquiera cierta forma que nos resulta familiar. Ese modo de hablar es la condición para que lo percibamos legítimamente como ese otro y confiemos en la veracidad de su palabra. Si una víctima, por ejemplo, no habla como una víctima debe hablar, entonces no confiamos en lo que dice y, por tanto, no la legitimamos como víctima. Esto ocurre desde las prácticas institucionales que imponen formatos para poder tener voz, hasta las prácticas cotidianas y mínimas en las que tenemos contacto con el otro, pasando, obviamente, por los registros audiovisuales de la voz. 
El problema de los códigos que hemos establecido para que el habla tenga legitimidad es que se piensan a sí mismos como transparentes, asumen que lo único que interesa de la voz es aquello que articula, aquellos contenidos que comunica. Se asume paradójicamente que la voz del testimonio no tiene un código, o que este es transparente. Del otro no nos importa cómo hable, sino que hable, porque en nuestra concepción de memoria lo que nos hace falta son contenidos. Por eso, hemos incorporado formas naturalizadas de la voz, sin preguntarnos en ocasiones a quién sirven esas formas, en qué contextos se originaron y pudieron tener utilidad, a qué medios y espacios de circulación corresponden. El problema de esta naturalización de los códigos es, precisamente, que la víctima puede terminar hablando el lenguaje del victimario y sirviendo directamente a sus intereses. Incluso, la voz misma de la víctima puede terminar por invisibilizar aquello que denuncia. Cuando la voz misma no se cuestiona, cuando el medio se da por hecho, el testimonio repite estructuras y códigos familiares con los que nos hemos acostumbrado a narrar "lo real". Hoy, el problema no es solo que las víctimas hayan estado privadas de voz durante mucho tiempo, sino que se las ha impuesto el imperativo de hablar de distintas maneras, se les ha puesto un micrófono y una cámara enfrente, se les han entregado distintos medios y se les ha exigido que hablen. Y lo han hecho, obviamente, con los lenguajes que creen que corresponden a esos medios. Gran parte de las víctimas que conocemos se han hecho visibles mediáticamente en tanto hablan un lenguaje conocido, en tanto se corresponden con sus propias representaciones. Hay un régimen de visibilidad (compuesto por una serie de representaciones diversas) dentro del cual la víctima se hace visible como tal.

Del mismo modo que esta sobrecodificación se hace visible en el testimonio y en la voz, aparece también en otro tipo de estrategias de visibilización de aquellos que han sufrido el conflicto (Arias, 2005). Uno de los más comunes, y que compone el objeto de esta investigación, es la visibilización del rostro. Todos hemos visto en algún momento lugares, objetos o acciones en los que, con el objetivo de denunciar actos de violencia, se exponen públicamente los rostros de las víctimas. En los museos que conmemoran grandes masacres colectivas, es común encontrar, por ejemplo, 
grandes murales con los rostros de cientos de víctimas, una al lado de otra (como sucede, por ejemplo, en el Museo del Genocidio de Tuol Sleng en Camboya, o en el Museo del Holocausto en Kalavryta, Grecia). En el campo de la producción audiovisual, la visibilización colectiva de rostros también ha sido usada como estrategia central, como ocurre en el documental colombiano Rostros de la memoria producido por el Centro Nacional de Memoria Histórica (CNMH, 2015).En muchos casos, las víctimas mismas han usado esta práctica como estrategia de manifestación pública para denunciar los actos violentos en contra de sí mismos o de sus allegados. Un ejemplo, entre muchos, es el llamado Salón del Nunca Más creado por un grupo de víctimas en el municipio de Granada, departamento de Antioquia (Hacemos memoria, s. f.). Uno de los componentes centrales del espacio es un mural con los rostros de todas las víctimas de la región que sus familiares han ido acumulando a través de los años para dar una dimensión del conflicto a cualquier visitante que se acerque al lugar. Cabe recordar, también, las múltiples manifestaciones alrededor del asesinato de los 43 normalistas desaparecidos en Ayotzinapa, México en septiembre de 2014 (Espinosa, 2014). Los medios masivos han reproducido la práctica de visibilizar los rostros como un modo de concientización de eventos trágicos. Ante ataques terroristas como los de París en 2015 o los de Orlando en junio de 2016 (Diario Las Américas, 2016; Clarín, 2015), los medios difunden los rostros de las víctimas.

Un ejemplo paradigmático es la estrategia de concientización acerca de la violencia sobre la infancia creada por el Fondo de las Naciones Unidas para la Infancia (Unicef) a principios de 2016. Esta se basaba en la creación de un personaje virtual llamado Sofía, una niña compuesta a partir de 500 fotografías tomadas a niños que viven en medio de conflictos armados alrededor del mundo. El objetivo de Sofía, en palabras de un portavoz de Unicef, es dar un rostro a todos los niños invisibles que son afectados por la guerra. En un video promocional, Sofía (nombre escogido por ser el femenino más popular del mundo) afirma mientras mira a la cámara: "Me llamo Sofía, tengo diez años, tuve que huir cuando hombres armados entraron en nuestra casa. Me llamo Sofía, tengo siete años, estoy en una lancha neumática, hace frío, el agua me llega hasta las rodillas. Me llamo Sofía, tengo 
cinco años y quisiera volver a la escuela". Así, este personaje virtual buscaba encarnar en un solo rostro las experiencias de miles de víctimas alrededor del mundo.

Medios masivos, protestas populares, manifestaciones públicas simbólicas, memoriales (espontáneos o institucionales), o piezas de arte. Existe una estrategia común de visibilización de las víctimas concentrada en la amplificación del rostro. Aunque parezca obvio, debemos preguntarnos: ¿por qué todas estas estrategias de visibilización, espontáneas o planeadas, tienden a privilegiar el rostro?

Son bien conocidas las múltiples prácticas de borradura del nombre y el rostro a través de la historia, desde la destrucción de estatuas y esculturas, o la eliminación del rostro en fotografías históricas, hasta las violentas prácticas de deformación o desaparición total del cuerpo de las víctimas que buscan siempre borrar cualquier registro o evidencia de una atrocidad singular. Le Breton (2009) sugiere que no hay violencia más perturbadora que aquella que atenta contra el rostro, en tanto esta diluye la identidad. Y no se trata simplemente de la violencia explícita sobre el rostro material, sino de toda práctica que impone la disolución de sí. Según Agamben (1998), la eliminación del rostro, cuando no implica la muerte biológica, cubre toda práctica que reduzca al otro a una vida desnuda (nuda vida). El ejemplo paradigmático de Agamben para explicar esta reducción es la figura del "musulmán" en los campos de concentración nazi: "los débiles, los ineptos, los destinados a la selección” (Levi, 2002, p. 49). Se trataba de prisioneros que habían llegado a un estado total de deterioro por desnutrición y abandono de la fuerza física, hasta el punto de que perdían toda conciencia de sí. Primo Levi (2002), en sus memorias de los campos, los describe como "presencias sin rostro" (p. 120). De este modo, la borradura del rostro implica un proceso de deshumanización y, por tanto, de exclusión de la historia. El sinrostro designa una presencia anónima, casi monstruosa. Es ahí donde radica la violencia de la borradura.

Las estrategias de visibilización de los rostros de las víctimas apuntan, precisamente, a resistir a esta violencia. Para Lévinas (1977), el rostro es el centro de lo humano en tanto es la base de la relación con el otro. El 
otro no es un individuo o una entidad abstracta, sino ante todo un rostro que me mira. Aquello que está en juego en la socialidad es primero un cara a cara en el que el otro me interpela y exige de mí una respuesta; soy responsable para con el otro. En esa medida, la borradura del rostro implica no solo la eliminación del otro, sino de cualquier vínculo social. Ahí radica la violencia del acto de borrar, así como la base de las prácticas que intentan humanizar a las víctimas dándoles un rostro. Dar un rostro al otro, reconocer su rostro, implicaría una restitución del vínculo social. El rostro tiene una potencia de resistencia que radica, como afirma Vollaire (2000), en "la singularidad irreductible que cada rostro opone a la despersonalización institucional” (p. 4). Mucho más aún cuando la violencia se institucionaliza.

Así, en primer lugar, el rostro opera como matriz de identificación. Le Breton (2009) afirma que dentro de los distintos componentes del cuerpo humano hay una jerarquía implícita, pues algunos tienen un valor más alto para el individuo o la comunidad: "En nuestras sociedades, el rostro y los atributos sexuales son social y culturalmente las partes más importantes del cuerpo [... Son los polos del sentimiento de identidad personal" (p. 141). Así, ante las múltiples prácticas que exponen a un pueblo a desaparecer, la visibilización ampliada del rostro busca devolver una singularidad, retornar una presencia concreta. El rostro acaba con el anonimato (un nombre es un dato, un rostro es una singularidad).

En segundo lugar, el rostro humaniza. Como bien señalaba Lévinas (1977), el rostro trae consigo la imposición de una alteridad que nos interpela, nos encara y, en esa medida, nos hace inmediatamente responsables. Esto podría explicar que la gran mayoría de las fotografías de rostros que se usan en muchas de las manifestaciones públicas contra la violencia miren directamente a la cámara y, a través de ella, encaren al espectador. Como lo señala Le Breton (2009), la matriz de identidad individual del rostro tendría un importante papel comunitario, en tanto se establece como lugar privilegiado de la aparición de "lo otro": "La singularidad del rostro evoca la del hombre, es decir, la del individuo, átomo de lo social, individis, consciente de sí mismo, amo relativo de sus decisiones, ante todo un 'yo' y no un 'nosotros"” (p. 143). El rostro es lo que nos enfrenta a un otro irreductible. 
Pagotto (2010) sintetiza lúcidamente la concepción del rostro en el pensamiento moderno: "El rostro es susurro de la identidad personal, es materia de símbolo, nace en el lazo social y encarna una ética al exigir responder por los propios actos. En síntesis, al rostro se le atribuyen tres funciones: a) individualizante, b) socializante (manifiesta en un rol social), y c) comunicante (asegura la comunicación entre dos personas y en el sí mismo)" (p. 3). Son estas tres funciones las que se ponen en juego en las prácticas y en los ejercicios de visibilización de las víctimas de la violencia a través de la exposición pública de sus rostros.

Ahora bien, ¿toda práctica de visibilización de los rostros de las víctimas consigue esa identificación y humanización en quien los percibe? ¿No corren el peligro estos rostros amplificados de convertirse en un código familiar que invisibilice las identidades que encarnan? Y aún más, ¿toda práctica de visibilización debe reducirse a una práctica de identificación de lo humano? Si bien autores como Vollaire destacan el valor del rostro individual señalando la singularidad irreductible que cada rostro opone a la despersonalización institucional, habría que preguntarse qué pasa cuando la institución asume la tarea, al menos retóricamente, de visibilizar personalizando. ¿Qué ocurre cuando las prácticas espontáneas de denuncia y protesta asumen una forma similar a la de los memoriales institucionales? Todas estas preguntas se condensan en una más fundamental: ¿cómo lograr que en una imagen del rostro aparezca una parcela de humanidad? Se trata entonces, afirma Didi-Huberman (2014), de "procurar que, pese a todo, aparezca una forma singular, una parcela de humanidad, por humilde que sea, en medio de las ruinas o la opresión" (p. 25).

\section{El rostro múltiple 0 borrado}

En 2005, Maritza Buitrago abandonó Landázuri, un pequeño municipio en el suroeste del departamento de Santander (Colombia), después de haber sufrido el asesinato de su padre y de su hermano mayor. Al primero lo asesinaron por resistirse a los cultivos declarados como ilícitos y por sus permanentes discusiones con miembros de grupos paramilitares. $\mathrm{Al}$ segundo, por haberse enterado de quién asesinó a su padre. Antes de que acabaran con toda la familia, Maritza decidió abandonar su tierra y sus 
animales junto con su hermana y su hija. Como muchos otros colombianos, Maritza se convirtió en una víctima del desplazamiento forzado que la obligó a establecerse en la capital del país. Solo un año más tarde decidió unirse a otras mujeres desplazadas para constituir un grupo que trabajara por los derechos de las mujeres que habían sufrido las consecuencias del conflicto armado. Desde 2008, con el Auto 092/2008, de 14 de abril, Corte Constitucional, este grupo se centró en el seguimiento y control de la ejecución de este fallo que reconocía la necesidad de adoptar medidas de protección especial a mujeres víctimas del desplazamiento forzado por causa del conflicto. El Grupo Distrital de Seguimiento al Auto 092 ha trabajado desde esa fecha para garantizar que se cumpla lo ordenado por la Corte: 13 programas para mujeres desplazadas que partan de su singular vulnerabilidad, órdenes de protección para 600 mujeres en todo el país y la comunicación a los organismos pertinentes de los crímenes sexuales cometidos en el conflicto armado.

Esta labor supuso que, desde 2009, Maritza volviera a enfrentar aquello que la había convertido en víctima en primer lugar: una serie de amenazas que la acusaban de ser un factor desestabilizante de las políticas del Gobierno y que prometían agredirla atrozmente si no abandonaba la vida pública y el trabajo social. Desde ese momento, han sido muchas las amenazas contra su vida e integridad. Cada una proveniente de distintas fuentes y enviadas por distintos medios. Pero todas con algo en común: una retórica del castigo en la que los actos violentos prometidos son resultado de las decisiones y acciones de Maritza. En una de ellas le recuerdan incluso el sitio "correcto" de la mujer, asociado al trabajo doméstico: "viejas locas creen que van a cambiar el país, ustedes nacieron para el maltrato, y trabajar en la casa, ustedes que están en esas mesas autónomas, en redes de mujeres, lsa $[$ sic $]$ vamos a matar... en movimientos de mujeres, y de defensa a los derechos humanos, vayan a cocinar que para eso nacieron. Por eso es que las violamos y no aprenden. Las golpiaron [sic] y no aprendrenden [sic]”. La lógica de la amenaza es clara: si ustedes, mujeres, han decidido participar en mesas de víctimas y en defensa de derechos humanos, es decir, si han decidido participar en el debate público, entonces las trataremos como un cuerpo público del que podemos disponer. La violación, mucho 
más que la muerte, se muestra como el castigo más recurrente para estas mujeres que han abandonado su espacio "natural" de lo doméstico. Bajo la lógica de esta amenaza, si se hubieran quedado en la cocina, nada les habría ocurrido (o les ocurrirá).

Cuando conocí a Maritza, a mediados de 2016, había recibido una nueva amenaza hace pocos días: "perras hijueputas dejen de meterse donde nadie las ha llamado, ya se les demostrado [sic] que existimos y cumplimos con lo prometido". Su nombre figuraba dentro de una larga lista de mujeres trabajadoras por los derechos de víctimas del conflicto precedida por las palabras “muerte, muerte, muerte”. El panfleto, firmado por las Águilas Negras le había llegado a través de su correo electrónico al igual que al resto de mujeres en la lista. Cuando me lo mostró, lo que más me impactó fue su serenidad, de modo que le pregunté si estas amenazas, a las que evidentemente ya se había acostumbrado, no producían ningún efecto en ella, sobre todo en su cotidianidad. Me respondió con un "no" tajante: no podía permitir que estos textos alteraran sus prácticas diarias, que la obligaran a esconderse y, sobre todo, a entorpecer la vida de su hija adolescente. Solo había una cosa que, sin embargo, se alteraba en su día a día. Para ella misma, era un miedo irracional, casi ridículo si se comparaba con los peligros que podía enfrentar saliendo a la calle y a lugares públicos: no le gustaba acercarse a la ventana de la sala de su casa, pues sentía que el vidrio se caería en cualquier momento. La ventana se convertía en el límite entre el adentro protector y el afuera amenazante. Ese límite se le volvía problemático por unas semanas. Después de unos días, afirmaba, el miedo desaparecía y su vida seguía su curso normal.

Esta narración dio origen a la videoinstalación En la ventana creada en 2016 gracias al trabajo conjunto con cuatro mujeres víctimas de la violencia del conflicto: Maritza, Yovana Sáenz, Yolanda Guzmán y Sofía Rivas. ${ }^{2}$ Un vidrio de 2,20 $\mathrm{m}$ de largo por 1,20 $\mathrm{m}$ de alto colgaba suspendido del techo por dos cuerdas metálicas en un cuarto vacío de paredes blancas. El vidrio estaba claramente resquebrajado; las grietas lo atravesaban en su totalidad.

2 La pieza fue expuesta por primera vez en la Muestra Internacional Documental de Bogotá. Un registro puede verse en https://vimeo.com/276865269 
Sobre él se proyectaban los rostros de las cuatro mujeres mientras leían distintos textos de amenazas que han recibido a lo largo de su vida. Las lecturas se fragmentaban, se sobreponían una a la otra, con el fin de subrayar las construcciones retóricas que sostienen a las amenazas: la lógica del castigo merecido, la reducción de la mujer a un cuerpo sexualizado, los insultos como forma de advertencia, entre otras. Los rostros seguían la misma operación formal a la que eran sometidas las voces: se fragmentaban siguiendo las líneas de las grietas que cubrían al vidrio (figura 1).

\section{Figura 1. En la ventana, videoinstalación, 2016}

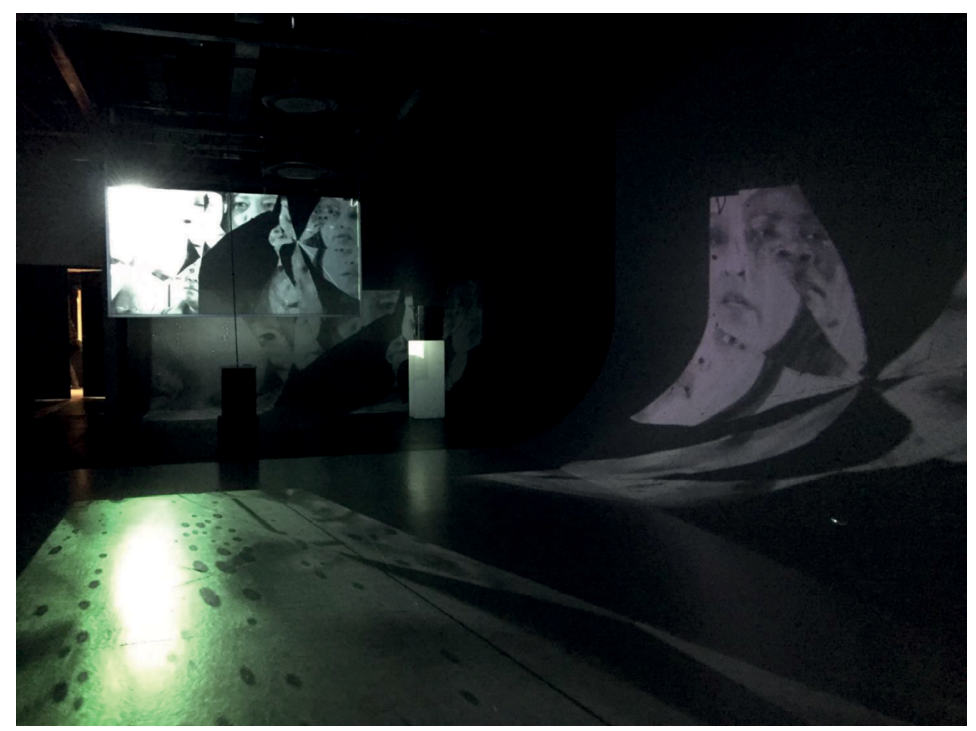

Fuente: archivo personal del autor.

Durante la exhibición pública de la videoinstalación, uno de los espectadores le preguntó a Maritza qué pensaba de la obra de la que era protagonista y que no había conocido hasta ese momento. Su primera reacción fue sonreír en silencio. No con una risa nerviosa, o que denotara que no sabía qué decir. Sino una sonrisa elocuente que le respondía a su interlocutor. Esta respuesta fue chocante para muchos: ¿cómo podía producirle gracia la situación de estar amenazada, de sentir que su vida entera tenía que reconfigurarse a partir de la violencia retórica que le "prohíbe" la acción pública en defensa de otras mujeres? Ante la tragedia del otro, cualquier reacción afectiva era legítima, excepto, tal vez, gracia o diversión. Ante los rostros 
desconcertados, Maritza aclaró su reacción: su voz mezclada con la de las demás mujeres, los rostros fragmentados superpuestos el uno al otro para formar uno nuevo, le hicieron pensar en las brujas, personajes que hablaban otras lenguas (indescifrables para el resto de mortales) y que parecían poder cambiar de rostro mágicamente. Lo que le había causado gracia es que ella, como feminista, siempre se había pensado a sí misma como una bruja, y ahora veía esa imagen en el vidrio frente a ella.

La respuesta de Maritza, además de atacar un extendido prejuicio de que la víctima no puede entender las obras de las que es objeto a no ser que estén hechas en un lenguaje extremadamente simplificador, abría una interpretación de la videoinstalación que resultaba extraña incluso para mí como "autor" de la pieza: la fragmentación de los rostros y la voz, la cual podía leerse como una alusión al efecto devastador de la amenaza sobre el cuerpo de la mujer, podía ser entendida también como una potencia de resistencia al poner como eje central la figura de la bruja y su poder de transformación. Aunque la conexión general entre feminismo y brujería es tremendamente evocadora, ${ }^{3}$ quisiera concentrarme aquí en un aspecto puntual introducido por la alusión a la capacidad de la bruja de ocultar su identidad: el rostro múltiple y cambiante. Un rostro que se borra a sí mismo para producirse siempre como un otro.

La multiplicidad y la borradura parecieran ser principios radicalmente opuestos a lo que caracteriza a un rostro. Si un rostro es reconocible como tal, es porque logra erigirse como matriz de singularidad y, en esa medida, hace identificable a quien se encarna en él. Esa singularidad era precisamente la que daba al rostro su valor como eje de representación

3 La conexión entre las brujas y el feminismo no es, en ningún sentido, novedosa. Al final de la década de los sesenta en los Estados Unidos, por ejemplo, se fundaron varios grupos feministas bajo el nombre de W.I.T.C.H: la sigla, que originalmente significaba Women's International Terrorist Conspiracy from Hell, cambió varias veces de significado adaptándose a protestas específicas. Así, por ejemplo, para una serie de protestas contra la compañía telefónica Bell Telephone, la sigla significaba Women Incensed at Telephone Company Harassment. Otros significados asociados a la sigla fueron Women Inspired to Tell their Collective History Women Interested in Toppling Consumer Holidays. Los grupos, que han reiniciado su actividad recientemente, realizaban protestas por los derechos de las mujeres a través de acciones extravagantes y teatrales. En su primera intervención pública realizada el 31 de octubre de 1968, los grupos se tomaron las calles de Nueva York: disfrazadas como brujas, las mujeres recorrieron Wall Street conjurando un maleficio en contra del distrito financiero. 
de las víctimas del conflicto: para oponerse a las prácticas de desaparición y borradura, la imagen del rostro se erige como herramienta fundamental de identificación y humanización. El rostro singular se nos muestra como lo otro de la borradura. El primero pertenece a las víctimas, la segunda es el procedimiento de los victimarios. La separación parece tajante, y en esa medida estaríamos ante una solución simple: a las múltiples prácticas que intentan exponer a los pueblos a su desaparición y anonimato oponemos la singularidad de la identidad condensada en un rostro. Sin embargo, como se indicó, a pesar de su potencia de humanidad, el rostro también se codifica, es objeto de sobreexposición. Exponer rostros, en lugar de hacer visible a un otro que está ausente, puede terminar exponiendo a ese otro a su desaparición. ¿Podemos pensar, entonces, que la potencia del rostro para exponer al otro no radica en su singularidad, sino en su multiplicidad? Es en esta última en la que puede radicar su potencia para escapar del peligro de la sobreexposición.

Quisiera comparar dos series fotográficas de rostros para comprender este problema. La primera, analizada por Didi-Huberman (2014), es la serie Faces del fotógrafo francés Philippe Bazin. Estas imágenes fueron realizadas entre 1985 y 1986. Bazin trabajaba como interno de medicina en un hospital geriátrico en el que decide escribir su tesis de doctorado titulada Aspectos humanos y psicosociales de la vida en un centro de larga estadía. Para su estudio, se basa en personas que están hospitalizadas de por vida, o como señala Didi-Huberman, "hospitalizadas hasta la muerte" (p. 33). Con el fin de mostrar esos aspectos humanos de estos pacientes, Bazin decide ir más allá del estilo convencional e institucional de la literatura médica para realizar una descripción fenomenológica de la experiencia del lugar que superara su inhumanidad, marcada por el olvido y el desprecio del otro. El joven médico dedica tiempo a sus pacientes, habla con cada uno, los escucha, bromea, convoca su memoria. Sin embargo, nos indica Bazin, lo inhumano siempre parecía imponerse: "Al archivar la historia clínica de un enfermo, me di cuenta de que, quince días después de su muerte, me había olvidado por completo de su cara. Era incapaz de dar una cara al nombre que tenía frente a mí en ese legajo administrativo" (Didi-Huberman, 2014, p. 34). Es esta incapacidad la que lo conduce a la fotografía. 
Sus imágenes, afirma Didi-Huberman, exponen rostros en el umbral probable de la muerte, rostros destinados a desaparecer. El valor de esas fotografías, sin embargo, no está solo en las imágenes entendidas como resultado, sino en el gesto contenido en la práctica desde las que esas imágenes fueron producidas. Si Bazin consigue hacer visible ese umbral de lo vivo, es porque se dedica a un ejercicio detallado de observación que le implicó cambiar la naturaleza misma del mirar. Didi-Huberman (2014) cita a Lamarche-Vadel:

Gesto inaudito, gesto único, verdadero gesto humano de un joven médico el de romper con su tarea administrativa para instalarse a la cabecera de sus viejos pacientes y hablarles, mirarlos a la cara, fotografiarlos. Gesto político de verdadera política humana, a saber, gesto de protección de visibilidad de cada quien y sobre todo de aquellos que, para ser mirados, deben encontrar fuera de sí mismos y casi por azar la manera de acceder a su propio rostro y a la posibilidad de que se los encare y se los represente. (p. 39)

Bazin se aleja de la práctica institucional, estando inmerso en ella. Su gesto rompe con una relación establecida, jerárquica, esperada.

El segundo ejemplo es la obra Sudarios de la artista colombiana Erika Diettes. La instalación fue exhibida por primera vez en 2011 en la iglesia del Museo de Santa Clara en Bogotá. Consta de veinte fotografías en primer plano de mujeres cuyo rostro revela un profundo dolor. Las imágenes fueron producidas en encuentros que la artista programó con mujeres víctimas de la violencia, las cuales narraban las situaciones en que fueron obligadas a presenciar la tortura y el asesinato de sus seres queridos. Diettes capturaba los rostros de estas mujeres en los momentos más dolorosos de la narración. Las fotografías fueron impresas en blanco y negro sobre sedas que se descolgaban del techo en una evidente sensación de levedad.

A pesar de su expresividad afectiva, los rostros de Diettes carecen de la parcela de humanidad de la que habla Didi-Huberman y que, precisamente, logra Bazin en sus imágenes. O mejor, las imágenes de Sudarios nos ofrecen un artificio de humanidad en tanto apelan a mecanismos de identificación hipercodificados: una cadena previsible entre víctima, dolor y sacrificio. Sobre la obra de Diettes, Gamboa (2016) señala: 
No podemos olvidar que la maximización de la referencialidad (el estatuto de "realidad" de estos rostros) se produce mediante una calculada puesta en escena, donde la artista edifica una escenografía (telones, luces, pantallas, cámaras y trípodes), en la que interactúan personas (terapeuta, víctimas y fotógrafa) siguiendo un guion determinado (las víctimas son convocadas para volver a narrar su historia, la terapeuta guía la narración, la fotógrafa "dispara" en los momentos más intensos de la narración). Una vez hechas las tomas, la artista selecciona las imágenes que considere más pertinentes. (p. 34)

Debe subrayarse que el problema no es que exista una puesta en escena. No se trata de un asunto de falsedad de la representación, sino que esta puesta en escena en ningún momento implica un gesto de dislocación de las prácticas institucionales respecto del tratamiento de la voz y el rostro de las víctimas. Dentro de la práctica que da origen a las imágenes, cada uno desempeña el papel que debe desempeñar: la terapeuta convoca y controla el testimonio (desde la seguridad que le proporciona el saber médico), la artista registra las imágenes (desde la seguridad que le proporciona el saber estético y técnico), y la víctima narra su dolor (así suene paradójico, desde la seguridad que le proporciona el ser catalogada como "víctima"). ¿Qué es, entonces, lo que logra Bazin al dislocar las prácticas y cuestionar el estatuto mismo del mirar a través de la cámara?

Esta simple y muy rápida comparación, me lleva a proponer una salida posible al problema de la sobreexposición del rostro: la necesidad de superar la comprensión dual y excluyente entre rostro y borradura. Es decir, comprender la borradura como parte de los rostros que se hacen visibles, y no como su otro exterior y siempre ajeno. Esto es, precisamente, lo que lograba Bazin en sus imágenes: encarar "el difícil trabajo de exponer esa misma exposición de los pueblos a hundirse, a desaparecer" (Didi-Huberman, 2014, p. 31). En otras palabras, mostrar lo que está destinado a borrarse, en tanto destinado a borrarse. Mostrar el acecho permanente de la borradura a través de la borradura misma hecha imagen. Al hacerlo, al hacer visible la exposición de los pueblos a desaparecer, se rescata una parcela de humanidad: siempre que la humanidad se expone como residuo expuesto a desaparecer, se revela al mismo tiempo como supervivencia destinada a mantener su proyecto vital, pese a todo. Pese a la deshumanización, al acecho de la desaparición. 
Permítaseme una comparación más. En 2010, la entonces presidenta de Chile, Michele Bachelet, inauguró en Santiago de Chile el Museo de la Memoria y los Derechos Humanos. Su objetivo era, como se expone en su página web oficial, "dar visibilidad a las violaciones a los derechos humanos cometidas por el Estado de Chile entre 1973 y 1990". Entre las muchas piezas y espacios dedicados a la memoria, uno sobresale como el eje central del Museo: un gran memorial ubicado en el segundo piso en el que se exponen fotografías de los rostros de los desaparecidos durante la dictadura de Augusto Pinochet. En frente de las imágenes, una pantalla táctil ofrece al espectador la posibilidad de ver la información recolectada de cada foto, como el nombre y la historia de cada víctima. Un objeto de naturaleza similar se encuentra ubicado en el subsuelo del museo a $6 \mathrm{~m}$ de profundidad: la obra Geometría de la conciencia, de Alfredo Jaar. La pieza reproduce, en cierto sentido, la lógica del memorial, al enfrentar al espectador a una pared con imágenes de las víctimas. Sin embargo, en lugar de rostros singulares identificables, solo se encuentran sus siluetas remarcadas por una luz que viene del interior del muro. Las siluetas pertenecen tanto a desaparecidos durante la dictadura como a ciudadanos chilenos vivos en el presente. Las demás paredes han sido recubiertas con espejos, de modo que la cuadrícula de siluetas parece extenderse hasta el infinito. Los espectadores son guiados al lugar en el cual permanecen por un periodo de 60 s. La disposición de la luz es fundamental: ubicada dentro de la pared, aumenta progresivamente durante 1 min hasta llegar a su punto más alto. Inmediatamente todo se apaga dejando al espectador en completa oscuridad por otros $60 \mathrm{~s}$. El efecto del contraste entre luz y oscuridad es intenso: el residuo luminoso de las siluetas queda grabado en la retina produciendo una especie de imagen fantasma.

Me interesa subrayar tres aspectos primordiales en la obra de Jaar con el fin de profundizar en el asunto de la borradura del rostro como posibilidad de exposición. Primero, Geometría de la conciencia funciona como una especie de negativo del memorial que se ubica dos pisos por encima de ella: el rostro vacío versus el rostro como matriz de identificación; el rostro como pura forma que se fija en la retina versus el rostro como fuente de información y contenidos; el rostro borrado inidentificable versus el rostro 
presente y reconocible. En resumen, el rostro múltiple versus el rostro antropológico (singular). Jaar expone, casi en negativo, la lógica del memorial. El memorial, más que hacer visibles singularidades irreductibles, hace visibles los intereses institucionales en la memoria, un deber ser del recordar. El problema surge cuando los creadores, incluidas las víctimas mismas, hacen suya la lógica del memorial como estrategia válida de visibilización de sí mismos o del otro que ya no está. Y no hablo solo de la disposición material del memorial, sino de su lógica interna, independiente de cuál sea la forma que asuma. Muchos productos audiovisuales siguen operando como memoriales consciente o inconscientemente. Jaar, en cambio, plantea una fuerte crítica a la institucionalidad. La disposición subterránea de la instalación, por ejemplo, alude sutilmente a la propiedad privada sobre las imágenes históricas: empresas como Corbis en Chile poseen los derechos de reproducción de una gran cantidad de medios de comunicación e imágenes históricas, las cuales se almacenan refrigeradas a $22 \mathrm{~m}$ bajo tierra en una instalación llamada Montaña de Hierro (Olivares, 2010). Jaar nos recuerda que la imagen, a pesar de su valor histórico, responde siempre a ciertos intereses; la imagen también puede ser una propiedad.

El segundo aspecto que me interesa en la pieza es el modo como hace indiferenciables el rostro de una víctima del rostro de un individuo cualquiera, contemporáneo del mismo Jaar. El otro que observa ya no está fuera, en el sitio privilegiado y seguro del "no ser víctima". La distancia se deshace, no por un proceso de identificación piadosa con el dolor del otro, sino por un borrado radical de la singularidad. Las siluetas vacías nos recuerdan la violencia radical que cayó sobre aquellos seres humanos, su desaparición forzada, todas las prácticas de desingularización a las que fueron sometidos; pero, al mismo tiempo, las siluetas fundan un nuevo espacio de comunidad en el que compartimos un espacio perceptivo de anonimato.

El último aspecto es el efecto de las imágenes en el espectador. Claramente, el objetivo de la pieza no es informar sobre una serie de singularidades (identificables por el que observa), sino generar una marca perceptiva, efímera, pero bastante sugerente. En lugar de enfrentar al espectador a rostros concretos y únicos, lo introduce en un dispositivo en el que lo convierte en una pantalla de rostros fantasmas. Como afirma Olivares (2010), "el 
lugar de la memoria se convierte en un tipo de sala de cine donde se personaliza la pantalla de proyección según la interacción mnemónica de cada visitante". A través de este elemento perceptivo, y de los dos mencionados, la obra genera un efecto dialéctico muy singular. En la instalación de Jaar, la exposición por desaparecer, es decir, el borrado de los rostros, revela, al mismo tiempo, la posibilidad de una supervivencia: la supervivencia del fantasma en la pantalla-ojo, o la supervivencia de una nueva comunidad de rostros en la que la distancia entre el que contempla y la víctima contemplada ha desaparecido.

\section{Por una política del rostro}

¿Cuál es, entonces, la potencia de hacer visible la borradura del rostro? ¿De deshacer los rostros en tanto matrices de identidad? Condensando lo afirmado hasta ahora, podríamos responder que la potencia de la borradura es la desnaturalización del rostro. Deleuze (2006) afirma: "Pensamos que el rostro es un producto, y que no todas las sociedades lo producen, sino solo aquellas que lo necesitan. ¿Por qué y en qué casos?” (p. 44). En Mil mesetas (1994), Deleuze, junto a Guattari, llega, incluso, a definir el rostro como un proceso permanente de sobrecodificación:

Incluso humana, la cabeza no es forzosamente un rostro. El rostro solo se produce cuando la cabeza deja de formar parte del cuerpo, cuando deja de estar codificada por el cuerpo, cuando deja de tener un código corporal polívoco multidimensional —cuando el cuerpo, incluida la cabeza, está descodificado y debe ser sobrecodificado por algo que llamaremos rostro. (p. 176)

Desde su perspectiva, el rostro reduce la multiplicidad del cuerpo. Este queda significado bajo un solo código para que pueda pasar por allí el susurro de la identidad personal. Lo que intentan Deleuze y Guattari en su análisis es desnaturalizar el rostro, mostrar que histórica y culturalmente ciertos agenciamientos de poder tienen necesidad de producir rostros y otros no. No tenemos naturalmente un rostro; somos introducidos en él. El rostro humano requiere siempre una producción social, y es por tanto una política. Así, "si el rostro es una política, deshacer el rostro también es otra política, que provoca devenires reales, todo un devenir clandestino" (1994, p. 192). 
Desde esta perspectiva, el gesto de deshacer el rostro puede contener una potencia política en tanto cuestiona y desnaturaliza una serie de supuestos en nuestra relación con el otro.

Las observaciones realizadas sobre la voz se hacen igual de relevantes para el caso del rostro. Parafraseo: el problema de los códigos que hemos establecido para que el rostro tenga legitimidad es que se piensan a sí mismos como transparentes, asumen que lo único que interesa del rostro es aquello que articula, aquella identidad que visibiliza y comunica. Se asume paradójicamente que el rostro no tiene un código, o que este es transparente. Hemos incorporado formas naturalizadas del rostro sin preguntarnos en ocasiones a quién sirven esas formas, en qué contextos se originaron y pudieron tener utilidad, a qué medios y espacios de circulación corresponden.

Ahora bien, ¿cómo podría pensarse esta dislocación del rostro desde las prácticas artísticas? En su influyente libro La imagen-tiempo (2004), Deleuze dedica un capítulo a la relación entre el cine y el cuerpo. No le interesa, sin embargo, el cuerpo como sujeto de acciones, sino lo que él llama gestus: "El vínculo o el nudo de las actitudes entre sí, su coordinación recíproca, pero en cuanto no depende de una historia previa, de una intriga pre-existente o de una imagen-acción” (p. 255). Uno de sus ejemplos es el cine de John Cassavetes en el que se disuelve la historia o la intriga para dar paso a un cine de los cuerpos en el que los personajes se reducen a sus propias actitudes corporales teatralizadas ante la cámara. Eso es lo que ocurre, por ejemplo, en Faces (Cassavetes, 1968): la película "se construye sobre las actitudes del cuerpo presentadas como rostros que llegan hasta la mueca, que expresan la espera, la fatiga, el vértigo, la depresión” (p. 256).

Una larga línea del cine experimental se ha dedicado a hacer visibles esos gestus, a extraerlos del flujo expresivo y comunicativo en el que, a pesar de percibirlos, los pasamos por alto para privilegiar sus contenidos. Las películas de Andy Warhol: seis horas sobre el rostro dormido. O los experimentos de los accionistas vieneses en los que, a través de la construcción de un ritual (iniciático y litúrgico), el rostro revela su plasticidad. Me interesa particularmente este último ejemplo, pues artistas como Günter Brus 
ubican en el centro de estos rituales la práctica de la borradura y la violencia sobre el rostro. El rostro, en piezas como Self painting, self mutilation de 1965 , se convierte en una matriz plástica. De modo similar a como el ojo se convertía en pantalla en la pieza de Jaar, aquí el rostro se convierte en lienzo para que la violencia de los trazos plásticos diluya su identidad.

A través de la noción de gestus, Deleuze nos señala dónde radica la potencia de las imágenes como espacios de borradura: ellas deben entenderse como movimientos que sacan a los rostros de su espacio expresivo natural y los vuelven artificiales. $O$ mejor, espacios que señalan la artificialidad constitutiva del rostro mismo. Espacios que borran la identidad, en los que el rostro deja de designar sujetos y señala corporalidades: la carnavalización (como en las pinturas de James Ensor), la teatralización, la exaltación de lo grotesco.

Esa artificialidad es la que se revela a través de los juegos de la puesta en escena en una película como Tout va bien (1972), de Jean-Luc Godard. Dentro de la historia, la periodista interpretada por Jane Fonda se dirige a una fábrica en huelga para realizar una serie de entrevistas a los trabajadores. Cada vez que habla con ellos, la cámara los muestra parados uno frente al otro en silencio. Una voz en off relata el texto de la entrevista, sin que sepamos a quién corresponde la voz. Lo suponemos solo porque en un determinado momento la cámara asume la posición de quien entrevista, y los rostros de los trabajadores nos encaran directamente en silencio. Las entrevistas de los trabajadores contrastan con la entrevista del dueño de la fábrica, quien habla y gesticula directamente a la cámara desde su escritorio. Los rostros de los trabajadores, los excluidos y marginalizados, guardan silencio frente a la cámara y la miran pacientemente. Se vuelven incómodos, artificiales. No se corresponden con una voz y, por tanto, no tienen un contenido. Son cuerpos, presencias en huelga. Llaman la atención sobre sí mismos, pues no deberían estar allí, en esa imagen, de ese modo particular. La identidad del que habla se diluye para convertirlo en gestus. El patrón tiene palabra, tiene un rostro que lo identifica. Los trabajadores tienen (son) gesto en tanto se ha borrado su singularidad. En este contraste, se condensa la potencia de la imagen como lugar de disolución de los rostros y de aparición de los gestos. 


\section{Referencias}

Agamben, G. (1998). Homo sacer: el poder soberano y la nuda vida. Valencia, España: Pre-Textos.

Agamben, G. (2001). Medios sin fin. Valencia, España: Pre-Textos.

Arias Herrera, J. C. (2005). Dar la voz, dislocar la imagen: visibilidad de las víctimas en el documental contemporáneo. Cuadernos de Cine Colombiano, 23, 90-99. Recuperado de http://www.academia. edu/31331602/La_visibilidad_de_las_v\%C3\%ADctimas_en_ el_documental_contempor\% $3 \%$ Alneo

Auto 092/2008, de 14 de abril, Corte Constitucional.

Benjamin, W. (2012). Paralipómenos y variantes de las "tesis sobre el concepto de historia”. En Autor, Escritos franceses. Buenos Aires, Argentina: Amorrortu.

Brus, G. (1965). Self painting, self mutilation. Recuperado de http://arpeggia.tumblr.com/post/38157514442

Cassavetes, J. (Dir.) (1968). Faces. The Walter Reade Organization. Distribuida por Continental Distributing [USA].

Centro Nacional de Memoria Histórica. (2015). Rostros de las memorias [Documental]. Recuperado de http://www.centrodememoriahistorica.gov.co/noticias/noticias-cmh/rostros-de-las-memorias

Clarín. (2015, noviembre 17). Crean una cuenta de Twitter para recordar a las víctimas de los atentados en París. Recuperado de https:// www.clarin.com/mundo/crean-twitter-victimas-atentados-parisenmemoire_0_BkusNlFw7x.html

Deleuze, G. (2002). Francis Bacon: lógica de la sensación. Madrid, España: Arena libros. 
Deleuze, G. (2004). La imagen-tiempo. Barcelona, España: Paidós.

Deleuze, G. (2006). Conversaciones. Valencia, España: Pre-Textos.

Deleuze, G. y Guattari, F. (1994). Mil mesetas. Valencia, España: Pre-Textos.

Diario Las Américas. (2016). Los rostros de las víctimas del ataque en Orlando. Recuperado de https://www.diariolasamericas.com/florida/los-rostros-las-victimas-del-ataque-orlando-n3873367

Didi-Huberman, G. (2013). Exponer a los sin nombre. En J. Barja y C. Rendueles (Eds.), Mundo escrito: 13 derivas desde Walter Benjamin, 1531. Madrid, España: Pensamiento.

Didi-Huberman, G. (2014). Pueblos expuestos, pueblos figurantes. Buenos Aires, Argentina: Manantial.

El País (2015, diciembre 19). Este gobierno le dio visibilidad a la víctimas: ministro para el postconflicto. Recuperado de https://www.elpais. com.co/proceso-de-paz/este-gobierno-le-dio-visibilidad-a-la-victimas-ministro-para-el-postconflicto.html

Espinosa, V. (2014, diciembre 1). Exhiben en Montreal mural con retratos de los normalistas de Ayotzinapa. Proceso. Recuperado de https:// www.proceso.com.mx/389582/exhiben-en-montreal-mural-conretratos-de-los-normalistas-de-ayotzinapa

Fondo de las Naciones Unidas para la Infancia. (2016, abril 12). MötSofia. Recuperado de https://www.youtube.com/watch?v=oKTnkXLfroo

Gamboa, A. (2016). Víctimas del arte: reflexiones en torno a la representación de la guerra en Colombia. Calle 14: Revista de investigación en el campo del arte, 11(19), 30-42. DOI: 10.14483/udistrital.jour. c14.2016.2.a03

Godard, J.-L., Gorin, J.-P. y Groupe Dziga Vertov (Dirs.) (1972). Tout va bien. Coproducción Francia-Italia. 
Hacemos memoria. (s. f.). Salón del Nunca Más. Recuperado de http:// hacemosmemoria.org/tag/salon-del-nunca-mas/

Le Breton, D. (2009). El rostro y lo sagrado: algunos puntos de análisis. Universitas Humanística, 68, 139-153. Recuperado de: https://revistas. javeriana.edu.co/index.php/univhumanistica/article/view/2270

Levi, P. (2002). Si esto es un hombre. Barcelona, España: Muchnik.

Lévinas, E. (1977). Totalidad e infinito. Salamanca, España: Sígueme.

Ley 1448/2011, de 10 de junio, por la cual se dictan medidas de atención, asistencia y reparación integral a las víctimas del conflicto armado interno y se dictan otras disposiciones.

Museo de la Memoria y los Derechos Humanos. (s. f.). Sobre el museo. Recuperado de https://ww3.museodelamemoria.cl/sobre-el-museo/

Olivares, L. (2010). La geometría de la conciencia: un archivo introductorio. Emisférica, 7(2). Recuperado de http://hemisphericinstitute. org/journal $/ 7.2 /$ multimedios/jaar/

Pagotto, M. A. (2010). Gilles Deleuze y Félix Guattari: políticas del rostro. Ponencia presentada en VI Jornadas de Sociología de la UNLP, La Plata, Argentina.

Sarlo, B. (2005). Tiempo pasado. Buenos Aires, Argentina: Siglo XXI.

Urna de Cristal. (2013, noviembre 28). ¿ Por qué es importante darle voz a las víctimas? Recuperado de http://m.urnadecristal.gov.co/radio/por-qu-es-importante-darle-voz-a-v-ctimas

Vollaire, C., Bazin, P., y Didi-Huberman, G. (2000). La radicalisation $d u$ monde. París, Francia: Lectoure. 